http://dx.doi.org/10.15762/ZH.2015.44

TOMASZ ŁASZKIEWICZ

(Instytut Historii PAN)

\title{
ZIEMIAŃSCY EGZULANCI KRESOWI NA POMORZU PO PIERWSZEJ WOJNIE ŚWIATOWEJ
}

Słowa kluczowe: ziemiaństwo, uchodźcy, migracje, Kresy Wschodnie, województwo pomorskie, II Rzeczpospolita

Działania wojenne między państwami centralnymi a Rosją, toczące się w okresie pierwszej wojny światowej na ziemiach dawnej Rzeczypospolitej, były przyczyną intensywnych procesów migracyjnych. Dotyczyło to zwłaszcza tzw. Kresów Wschodnich, gdzie front utrzymywał się najdłużej i toczyły się zacięte boje. Zamieszkująca te tereny ludność masowo opuszczała swoje domy w obawie przed utratą życia ${ }^{1}$. Zawieszenie działań militarnych między Niemcami i bolszewicką Rosją, a później koniec wojny oraz powstanie niepodległego państwa polskiego nie oznaczały bynajmniej stabilizacji politycznej dla Kresów. Polskie elity przywódcze nie miały jednolitej koncepcji ukształtowania granicy wschodniej, co negatywnie odbiło się zarówno na działaniach dyplomatycznych, politycznych, jak i później militarnych. W efekcie traktat ryski, kończący wojnę polsko-bolszewicką, był kompromisem, który pozostawiał rzesze Polaków pod władzą bolszewicką. Mieszkający tam ziemianie ponosili w pewnej mierze konsekwencje własnej polityki, krótkowzroczności i braku zrozumienia dla koncepcji polityki wschodniej Naczelnika Państwa ${ }^{2}$. W żadnej mierze nie umniejsza to jednak skali dramatu, jaki stał się udziałem poszczególnych rodzin, tak plastycznie oddanego np. w Pożodze Zofii Kossak-Szczuckiej ${ }^{3}$. Ziemianie pozbawieni własności, jako wrogowie ludu w państwie sowieckim, zostali skazani na los tułaczy.

Uchodźcy utracili nie tylko domy, fabryki, majątki ziemskie, które stanowiły podstawę ich egzystencji. Opuszczając swoje siedziby, często w pośpiechu, zostawiali tam ruchomości i zbiory artystyczne gromadzone przez pokolenia. Wielu

\footnotetext{
${ }^{1}$ Por. Mariusz Korzeniowski, Marek MąDzik, Dariusz Tarasiuk, Tułaczy los. Uchodźcy polscy w imperium rosyjskim $w$ latach pierwszej wojny światowej, Lublin 2007.

${ }^{2}$ Joanna GIERowsKa-KaŁŁaur, Zarząd Cywilny Ziem Wschodnich (19 lutego 1919 - 9 września 1920), Warszawa 2003, s. 328 n., 375-376.

${ }^{3}$ Zofia Kossak-Szczucka, Pożoga. Wspomnienia z Wolynia 1917-1919, Warszawa 1996 (wyd. 2).
} 
z nich pozostawiło też znaczne oszczędności w postaci środków pieniężnych, biżuterii i kruszców zdeponowanych w bankowych sejfach, których nie zdążyli podjąć na czas ${ }^{4}$. Innym opuszczającym nieco wcześniej tereny Ober-Ostu z wojskiem niemieckim udawało się zdobyć wagony i koleją ekspediować inwentarz gospodarczy oraz dobra osobiste. Bez względu na urodzenie, dotychczasowy status społeczny i ekonomiczny stawali się grupą egzulantów pozbawionych szerszych perspektyw. Jeszcze w czasie wojny polsko-bolszewickiej licznie zjechali do stolicy, często szukali schronienia u rodzin w Polsce centralnej lub zachodniej. Uchodźcami ze wschodu zapełniły się także Poznań, zwłaszcza Toruń i Bydgoszcz, które po wyjeździe stąd Niemców dysponowały dużym zapleczem mieszkaniowym ${ }^{5}$. Najczęściej żywili jeszcze nadzieje, że w wyniku sukcesów polskich w wojnie z bolszewikami uda im się odzyskać utracone majątki. Kiedy tylko warunki na to pozwalały, próbowali wracać i doglądać swoich dóbr. Najczęściej dwory były splądrowane, folwarki ogołocone z inwentarza i płodów rolnych. Ofensywa bolszewicka późną wiosną 1920 r. zmusiła ziemian kresowych do ostatecznej ucieczki ze swoich posiadłości. Podążali do swoich rodzin mieszkających na zachodzie, ale linia frontu posuwała się szybko, wyrzucając ich coraz dalej z krewnymi, których wsie wcześniej wydawały się bezpiecznym azylem. Tak 7 VII 1920 r. Woyniłłowiczowie opuszczali Sawicze pod Mińskiem, ciągnąc ze sobą dobytek na kilku wozach. Po czterech dniach podróży stanęli u Bielskich w Atteczyźnie pod Kobryniem. Przebywali tam zaledwie dwa tygodnie, by w dalszą drogę ruszyć z Bielskimi. Wspólnie dotarli do kolejnych krewnych na Lubelszczyźnie ${ }^{6}$. Stąd Edward Bielski udał się jeszcze dalej, na pogranicze Wielkopolski i Pomorza, do swoich teściów - Komierowskich, gdzie wcześniej zdążył wyekspediować koleją liczne ruchomości. Tam również dotarł tabor koni pędzonych aż zza Buga?

W ciągu letnich miesięcy 1920 r. dwory Wielkopolski i Pomorza zapełniły się uchodźcami. Udzielano im schronienia, zapewniano utrzymanie nieraz przez wiele miesięcy. W stajniach znajdowano miejsce dla ocalonych resztek stad koni ${ }^{8}$. Kresowi ziemianie żyli w przygnębieniu, niepewni o losy bliskich, przybici utratą majątku, zatroskani o swoją przyszłość. Roman Komierowski, który w liście do syna relacjonował swój pobyt w Kościelcu na Kujawach, wymieniał przebywających tam uchodźców. Wśród nich był hrabia Ludwik Plater-Zyberk z córką, drugi nieustalony z imienia Plater-Zyberk również z córką, prawdopodobnie baronowa

${ }^{4}$ Zofia STUlgiŃsKa, Gruszki na wierzbie. Wspomnienia, Warszawa 1972, s. 12.

${ }^{5}$ Janina Żó£тowska, Dziennik. Fragmenty wielkopolskie 1919-1933, oprac. Barbara Wysocka, Poznań 2006, s. 97; Gizela Chmielewska, Kolonia wygnańców. Bydgoszczanie z Kresów Wschodnich 1920-1939, Kronika Bydgoska, t. 35: 2014, s. 41-62.

${ }^{6}$ Edward WoyniŁŁowicz, Wspomnienia 1847-1928, cz. 1, wyd. Janusz IwaszKiewicz, Wilno 1931, s. 289-294.

${ }^{7}$ Archiwum Państwowe w Bydgoszczy (dalej cyt. APB), Archiwum Komierowskich (dalej cyt. Kom.), sygn. 56, list Romana Komierowskiego do Róży z Zamoyskich Komierowskiej z 27 VIII $1920 \mathrm{r}$.

${ }^{8}$ Roman Komierowski, „Moje wspomnienia od 15 kwietnia do dzisiejszego dnia”, rękopis wspomnień spisany w czerwcu 1921 r., w zasobie: APB, Kom., sygn. 32, s. 2-3. 
Janina Hartingh z synem, wdowa Jadwiga Łubieńska oraz kilka osób nieznanych z nazwiska. Komierowski krótko charakteryzował poznanych ludzi. Dzięki temu możemy poczuć nastrój panujący w kujawskim dworze i zaobserwować różne postawy goszczących tam ziemian. O jednym z nich pisze mianowicie: „Ten drugi pan Plater zupełna ruina po ciężkich przeżyciach i chorobie - prawie wcale się nie udzielający”. O młodym Marcelim Hartinghu następująco: „pomocny w gospodarstwie, o czwartej rano na nogach, skromny i sympatyczny młodzieniec"9. Z jednej strony widzimy zatem załamanego człowieka, który utracił rodową spuściznę, nie widział dla siebie perspektyw i popadał w wyraźną depresję. Z drugiej natomiast młodzieńca chętnego do pracy, aby zarobić na utrzymanie w gościnnym dworze i nabrać potrzebnej dla ziemianina praktyki. Po odparciu ofensywy bolszewickiej pod Warszawą i odrzuceniu przeciwnika na wschód ci, którzy mogli, zaczęli wracać do swoich siedzib. E. Bielski pozostawił jeszcze w Nieżychowie pięcioro swoich dzieci aż do maja 1921 r., a sam z żoną udał się do Atteczyzny pod Kobryniem. Powróciwszy, zastawali najczęściej zniszczone i ograbione majątki, braki inwentarza i panujący głód. Na łasce krewnych pozostawały te rodziny, których majątki znalazły się poza kordonem granicznym. Wkrótce musieli zacząć układać sobie życie od nowa, zazwyczaj na znacznie niższym poziomie materialnym. Wielu przenosiło się do miast w poszukiwaniu pracy, najczęściej urzędniczej ${ }^{10}$.

Kluczowym problemem dla kresowych uchodźców po wojnie była właśnie kwestia zdobycia środków do życia. Niektórzy z nich borykali się z podstawowymi trudnościami egzystencjalnymi. Należał do nich Julian Ścibor-Marchocki, młodzieniec, który po zdemobilizowaniu w 1921 r. nie miał nic poza wytartym mundurem i dwiema zmianami bielizny. Był synem Juliusza i Jadwigi z Jaxa-Małachowskich, właścicieli Lubomiły. Jego ojcowizna leżała wśród dalekich stepów czarnomorskich, z której został wygnany przez wybuch rewolucji bolszewickiej. Ze względów finansowych nie mógł kontynuować studiów rozpoczętych w warszawskiej Szkole Głównej Gospodarstwa Wiejskiego i zatrudnił się jako praktykant-rządca w niewielkim folwarku Laury i Jerzego Walewskich na przedmieściach Kościerzyny na Pomorzu. Po zaręczynach z córką doktora Edwarda Hulewicza, znanego lekarza i ziemianina, gospodarującego w Pucu na Kaszubach, podjął naukę w Akademii Rolniczej w Bydgoszczy, którą ukończył po jej przeniesieniu do Cieszyna. Wkrótce ożenił się i został nauczycielem w toruńskiej szkole rolniczej, prowadzonej przez Pomorską Izbę Rolniczą, publikował też artykuły z zakresu doradztwa rolniczego ${ }^{11}$. Młodzi Marchoccy przenieśli się do majątku Górskich pod

\footnotetext{
${ }^{9}$ Ibid., sygn. 29, list Romana Komierowskiego do syna Tomasza z 16 IX 1920 r.

${ }^{10}$ R. Komierowski, op.cit., s. 7.

${ }^{11}$ Kalendarz nauczycielski na rok 1925, Tuchola 1924, s. 81; Pomorski Kalendarz Rolniczy na rok 1925, Toruń 1925, s. 75-79; Gazeta Sępoleńska, nr 140 z 30 XI 1929 r.; Stanisław Ścibor-MARCHOCKI, „Wspomnienia z lat przedwojennych i z wędrówki przez świat podczas wojny”, maszynopis spisany w latach osiemdziesiątych XX w., w zbiorach prywatnych Marii Ścibor-Marchockiej, s. 4; Roman Aftanazy, Dzieje rezydencji na dawnych kresach Rzeczypospolitej, t. 11: Województwo kijowskie, Wrocław 1997 (wyd. 2), s. 265; Kłosy, nr 21-22 z 30 V 1937 r., s. 343.
} 
Tucholą, gdzie Julian przyjął posadę rządcy. Powierzenie administracji jednego z większych majątków ziemskich na Pomorzu (ponad 3 tysiące hektarów) człowiekowi jednak niedoświadczonemu świadczyło o dużych zdolnościach Juliana Ścibor-Marchockiego. Warunki finansowe w Kamienicy były bardzo dobre, jednak ambitny młody człowiek zamierzał się usamodzielnić. Dlatego z końcem lat dwudziestych przeniósł się do Rumii pod Gdynią, gdzie wziął tamtejszy majątek ziemski (należący zresztą do innego uchodźcy - Dymitra Andrault de Langeron) w dzierżawę ${ }^{12}$.

W dużo lepszej sytuacji byli ziemianie kresowi, którzy mieli na Pomorzu rodziny lub w wyniku posagów czy działów rodzinnych otrzymali tutaj ziemię. Jednym z nich był Józef Szymon Meysztowicz z Ludyna na Litwie. Jego druga żona - Maria z Gółkowskich primo voto Mieczkowska - odziedziczyła po ojcu rodzinne Piecewo pod Jabłonowem Pomorskim. Małżonkowie przenieśli się tutaj jeszcze podczas wojny, choć Józef część czasu spędzał na Litwie. Kiedy jego dobra znalazły się pod administracją litewską, przeniósł się na stałe na Pomorze, gdzie piecewski majątek zapewniał dobre warunki utrzymania ${ }^{13}$. W podobnej sytuacji była kresowa rodzina księcia Stanisława Puzyny. Jego żona Kazimiera z Zielińskich jeszcze w XIX w. nabyła majątek Zębowo w ziemi dobrzyńskiej, położony wówczas w pobliżu granicy rosyjsko-pruskiej. Dlatego Puzynowie mogli się tutaj przenieść w niebezpiecznych czasach z najmłodszym synem Włodzimierzem. Ten ostatni poślubił swoją bliską krewną (bratanicę matki) Marię Letycję Zielińską ze Skępego, po czym za pieniądze uzyskane prawdopodobnie z posagu kupili od niemieckiej rodziny Wolffów ponad tysiąc hektarów ziemi z okazałym i nowoczesnym pałacem w Gronowie pod Toruniem ${ }^{14}$.

$\mathrm{W}$ rodzinne strony ściągnęła także z mężem i synem Maria $\mathrm{z}$ Donimirskich Świacka. Na ojcowiźnie w Łysomicach pod Toruniem gospodarował wówczas jej brat Jan, który udzielił uchodźcom schronienia na kilka najbliższych lat. Niemniej Świaccy musieli szukać pracy, aby zbudować sobie perspektywę nowego życia na Pomorzu. Również w tym przypadku rodzina okazała się pomocna. Karol Świacki otrzymał mianowicie posadę dyrektora Komisji Pomorskiej Zjednoczenia Producentów Rolnych, później dyrektora Pomorskiego Towarzystwa Rolniczego. Prezesem obu tych instytucji był wówczas wspomniany szwagier Świackiego - Jan Donimirski ${ }^{15}$. Maria trudniła się wykładaniem historii i języka polskiego w szkołach wiejskich, następnie pracowała w Pomorskim Towarzystwie Opieki nad Dziećmi. Z kolei ich syn Stanisław po odbyciu studiów znalazł posadę w Urzędzie Wojewódzkim Pomorskim. Referencji udzielił mu starosta toruński Adam Czarliński,

\footnotetext{
${ }^{12}$ Archiwum Państwowe w Gdańsku (dalej cyt. APG), Oddział w Gdyni (dalej cyt. O/Gdynia), Starostwo Morskie w Wejherowie (dalej cyt. SMW), sygn. 99; sygn. 3248.

${ }^{13}$ Gazeta Toruńska, nr 286 z 15 XII 1915 r., s. 4; Dzień Pomorski, nr 211 z 13 IX 1937 r., s. 8.

${ }^{14}$ Piotr GaŁkowski, Genealogia ziemiaństwa ziemi dobrzyńskiej XIX-XX wieku (do roku 1939), Rypin 1997, s. 124, 228.

${ }^{15}$ Pomorskie Towarzystwo Rolnicze. Sprawozdanie za rok 1924, Toruń 1925, s. 41; Gazeta Toruńska, nr 141 z 24 VI 1921 r., s. 3; Słowo Pomorskie, nr 176 z 4 VIII 1923 r., s. 4.
} 
także spokrewniony z Donimirskimi ${ }^{16}$. Świaccy po kilku latach pobytu na Pomorzu zdecydowali się zakupić niewielkie gospodarstwo rolne, które uniezależniłoby ich od etatowej pracy urzędniczej. Z pomocą w jego urządzeniu znowu przyszła rodzina Marii. Donimirscy odbyli w jednym ze swoich majątków naradę, na której zdecydowali o solidarnym wsparciu krewnych przez podarowanie im z własnych obór, chlewni i stajni niezbędnego inwentarza gospodarskiego ${ }^{17}$. Po sześciu latach przerwy Karol mógł z powrotem gospodarzyć na roli. Zmienił się jedynie areał gospodarstwa - tam, na Kresach, dysponował trzema folwarkami przekraczającymi 10 tysięcy hektarów, tutaj, na Pomorzu, nie miał nawet 50 hektarów.

Jako jeden z pierwszych kresowych ziemian na Pomorzu, ściśle w Gdańsku, którego status polityczny jeszcze nie był pewny, pojawił się Mieczysław Jałowiecki. Opuścił swoje Syłgudyszki na Litwie w ostatnich dniach 1918 r. i wkrótce otrzymał propozycję zorganizowania polskiego przedstawicielstwa przy wojskowej misji amerykańskiej, później został delegatem Rządu RP w Gdańsku. Dość szybko zaczął myśleć o kupnie majątku ziemskiego z rąk niemieckich. Upatrzył sobie nawet malowniczo położony wśród nadmorskich moren folwark Mały Kack. Położenie dworu, otaczający go starodrzew przypominał M. Jałowieckiemu rodzinne Syłgudyszki. Wszedł w pewną zażyłość z rodziną właścicieli - von Brauchitschów, którzy byli zainteresowani sprzedażą, a litewski arystokrata przypadł im do gustu. Jako przedstawiciel rządu polskiego w Gdańsku obawiał się jednak zarzutów o wykorzystywanie swojej posady dla prywatnych interesów. Prawdopodobnie doniesiono do Warszawy o planach $\mathrm{M}$. Jałowieckiego, a z kół rządowych lub parlamentarnych wywarto presję, aby od tej transakcji odstąpił. Z goryczą wspominał, że rok później majątek ten przejęło państwo polskie i odsprzedało na ulgowych warunkach Juliuszowi Jewelowskiemu, kupcowi i senatorowi gdańskiemu pochodzenia żydowskiego ${ }^{18}$. M. Jałowiecki świetnie realizował się w dyplomacji, jednak tęsknił do ziemi. Zamierzał nawet podjąć pracę na plantacjach kawy w Afryce, lecz w 1922 r. powtórnie się ożenił i osiadł w majątku żony w Kaliskiem.

Duża podaż ziemi na Pomorzu, wywołana emigracją Niemców, przyciągała również ziemian niemających swoistego „zaplecza” w postaci krewnych ${ }^{19}$. W niewielkim mająteczku na Kaszubach osiedli Maria i Medard Komarowie, którzy pozostawili Giełgudyszki na Litwie. Dobrze zagospodarowali się w Somoninie i oboje aktywnie włączyli się w życie społeczne regionu ${ }^{20}$. Bardzo szybko M. Komar został

${ }^{16}$ APB, Urząd Wojewódzki Pomorski (dalej cyt. UWPom.), akta osobowe - dopływ z MSW, sygn. 356, arkusz osobowy Stanisława Świackiego.

${ }^{17}$ Biblioteka Narodowa w Warszawie (dalej cyt. BN), sygn. akc. 11063, list Marii z Donimirskich Świackiej do syna Stanisława z 13 X 1924 r.

${ }^{18}$ Mieczysław Ja£owiecki, Na skraju Imperium i inne wspomnienia, Warszawa 2012 (wyd. 1), s. $510-513$.

${ }^{19}$ Por. Tomasz Łaszkiewicz, Ziemiaństwo na Pomorzu w okresie dwudziestolecia międzywojennego - w perspektywie codzienności, Inowrocław-Toruń 2013, s. 35-41, 63-65.

${ }^{20}$ Marek Ży LICZ, „Wspomnienia. 2. Zniszczone dwory”, maszynopis spisany w 2008 r., w zbiorach prywatnych Marka Żylicza, s. 35, 78-79; relacja prof. dr. hab. Marka Żylicza z 8 VII 2013 r. przekazana autorowi. 
prezesem kółka rolniczego w Goręczynie i pozostał nim niemal do śmierci. Kierował także kołem powiatowego Towarzystwa Powstańców i Wojaków ${ }^{21}$. Z racji, że był cenionym myśliwym, został wybrany delegatem powiatowym Pomorskiego Związku Łowieckiego, zajmując się m.in. opiniowaniem wniosków o pozwolenie na broń czy odstrzał zwierzyny trofeowej ${ }^{22}$. Z kolei jego żona Maria włączyła się do pracy w stowarzyszeniu Ziemianek Pomorskich, zostając wiceprezeską koła w Kartuzach ${ }^{23}$. Majątek Szpęgawa, przejęty przez państwo polskie z rąk spadkobierców tczewskiego przemysłowca Willego Muscata, został podzielony na kilka mniejszych gospodarstw. Jedno z nich (51 ha) kupił hrabia Aleksander Bolcewicz (wcześniej właściciel dóbr uciańskich na Litwie), któremu rzekomo udało się wykupić z niewoli bolszewickiej za dwa i pół kilograma złota. Nieopodal, już w granicach Tczewa, większy majątek kupił Stanisław Kozakowski, pochodzący z powiatu wiłkomierskiego. Z kolei na przedmieściach Kościerzyny były położone niewielkie (pięćdziesięciohektarowe) folwarki, które kupili Ledóchowscy z Ukrainy oraz Grocholscy z Podola. Dla tych ostatnich była to już trzecia po wojnie próba objęcia majątku, dwie poprzednie w Poznańskiem zakończyły się fiaskiem ${ }^{24}$.

Dobrą możliwość utrzymania dawało również wzięcie w dzierżawę jednej z licznych domen państwowych na Pomorzu, mimo że nie wszystkie były we właściwej kondycji gospodarczej. Wielu niemieckich dzierżawców, mając świadomość wypowiedzenia kontraktów przez nową polską administrację, prowadziło gospodarkę rabunkową, dewastując warsztat rolny. Pola były więc nienawożone, niedrenowane, narzędzia i maszyny rolnicze pozostawione bez napraw i remontów. W podobnym stanie był inwentarz żywy oraz zapasy ziarna siewnego. Niemniej gospodarstwa te wydawały się kwitnącymi, w porównaniu z ogołoconymi przez bolszewików folwarkami na Kresach Wschodnich Rzeczypospolitej. Dlatego wspomniany E. Bielski wziął w dzierżawę majątek Kończewice pod Chełmżą, ponieważ ze swojej Atteczyzny nie spodziewał się szybkich zysków. Tutaj przeniósł też rodzinę, a sam podróżował między folwarkami oddalonymi od siebie o przeszło $400 \mathrm{~km}^{25}$.

\footnotetext{
${ }^{21}$ APG, Powiatowa Komenda Policji Państwowej w Kartuzach, sygn. 4, wykaz wybitnych działaczy na terenie komendy powiatowej policji w Kartuzach; PTR. Sprawozdanie za rok 1924, Toruń 1925, s. 37; PTR. Sprawozdanie za rok 1935-36, Toruń 1936, s. 141.

${ }^{22}$ APB, UWPom., sygn. 2126, opinia starosty kartuskiego o delegatach powiatowych Związku Łowieckiego z sierpnia $1933 \mathrm{r}$.

${ }^{23}$ Ibid., sygn. 2110, sprawozdanie starostwa powiatowego w Kartuzach do urzędu wojewódzkiego w sprawie działalności organizacji kobiecych z $1931 \mathrm{r}$.

${ }^{24}$ Julian ŚCIBOR-MARсHOCKI, „Wspomnienia”, maszynopis przepisany z rękopisu przez syna Stanisława po 1972 r., w zbiorach prywatnych Marii Ścibor-Marchockiej, s. 95, 98; Jerzy ŻEnkiEwicz, Dwór polski i jego otoczenie. Kresy Pótnocno-Wschodnie, Toruń 2008, s. 93, 104; Gertruda PIERZYNOWsKa, Dwory, parki i folwarki Kociewia i Kaszub, Tczew 1998, s. 374.

${ }^{25}$ APB, Kom., sygn. 56, list Franciszki z Komierowskich Bielskiej do Róży z Zamoyskich Komierowskiej z 23 XII 1921 r.; ibid., list Romana Bielskiego do Róży z Zamoyskich Komierowskiej z 23 X $1921 \mathrm{r}$.
} 
Ta niewątpliwie różnorodna i zatomizowana grupa egzulantów kresowych miała jednak pewne cechy, które pozwalają mówić o niej w sposób odrębny. Pierwszą z nich była tęsknota do stron rodzinnych i silne poczucie wygnania. M. Jałowiecki wspominał z rozrzewnieniem jarmarki końskie w Wiłkomierzu, odpusty w Szadowie, polowanie na pardwy na Szepecie. Wszystko to porównywał z uporządkowanym „niemieckim” Pomorzem i nie znajdował przewagi zachodniej cywilizacji. Wprost przeciwnie: tutejsze hotele, zwyczaje czy usługi nie wytrzymywały porównania z jego ojczystą Litwą. Swoje opinie przenosił też na ludzi, bo „co mogą być warci ludzie, którzy nie zaznali rozkoszy przejażdżki pięknym gościńcem krakinowskim w powozie lub żółtej kałamaszce, zaprzęgniętej w czwórkę lub parę dobranych kasztanów, którzy w swoim życiu nie pijali starki montwiłłówki, nie znali smaku kołdunów lub chłodnika obficie okraszonego szyjkami rakowymi”26. Obszerny artykuł o urokach i roli Kresów Wschodnich ogłosił w pomorskiej prasie Stanisław Świacki. Wspominając rodzinne strony, malowniczo kreślił obraz dzikiej przyrody i mitycznego charakteru tej ziemi otulonej snującymi się mgłami. Tekst dotyczył jednak tej części Kresów, która pozostała w granicach Rzeczypospolitej, dlatego znaczna część artykułu była poświęcona roli tamtejszych dworów ziemiańskich, przedstawianych jako swoista tama przed bolszewizmem. W dwóch odcinkach opowiadał $\mathrm{z}$ autopsji o zniszczeniach majątków kresowych oraz ich stopniowej odbudowi ${ }^{27}$. Jego matka, która po latach przerwy $\mathrm{w}$ prowadzeniu domu, osiedliwszy się pod Chełmżą, otworzyła księgę gości i wpisała na początek gospodarowania w ziemi pomorskiej następujący wiersz:

„Po ciężkich burzach, biedni i znękani

Zawitaliśmy do cichej «Przystani»

By dach mieć własny i swój kawał ziemi

Co ma nas żywić kłosami chlebowemi.

Do chatki naszej kto dzisiaj zapuka

Dawnej świetności niech u nas nie szuka

Lecz w naszą przyjaźń i serca uwierzy

A ściana domku wnet mu się rozszerzy

Życiowe rozbitki Karolostwo Świaccy"28.

Zamieszczony podpis wydaje się bardzo wymowny i oddający stan ducha kresowej rodziny. W krótkich słowach wiersza M. Świacka wyraziła swoją krzywdę

\footnotetext{
${ }^{26}$ M. JAŁOWIECKI, op.cit., s. 533.

${ }^{27}$ Stanisław Świacki, Z kresów wschodnich, Słowo Pomorskie, nr 212 z 13 IX 1925 r., s. 4-5; idem, $Z$ kresów wschodnich (ciag dalszy), ibid., nr 215 z 17 IX 1925 r., s. 3-4.

${ }^{28}$ BN, sygn. akc. 11066, „Książka gości Bielice (z. mohylewska) i Przystań (k. Chełmży)”, rękopis zapisywany w latach 1909-1934, brak paginacji.
} 
i żal za utraconą ziemią. Beztroska, humor i szczęście minęły z rewolucją. Nowe gospodarstwo w Archidiakonce małżonkowie Świaccy romantycznie nazwali Przystanią, a mottem ich życia stała się wyłącznie praca. W wierszu jest też widoczny pewien kompleks „małej chatki”. Rodzina żyjąca dotąd w otoczeniu zamożnego dworu, licznej służby schodzi do znacznie skromniejszego, gospodarskiego życia. Autorka prosiła swoich gości, aby nie szukali w nowych murach dawnej świetności, a jedynie szczerości i przyjaźni gospodarzy. Anonimowy autor artykułu opublikowanego w toruńskim „Słowie Pomorskim” podobnie wyrażał rozpacz uchodźców kresowych. Wspominając swoje odczucia z jesieni 1918 r., pisał o jemu podobnych: „bogaci, do dobrobytu przyzwyczajeni - ze wszystkiego przez bolszewików ogołoceni, głodni i odarci... tęskniący za ziemią ojczystą"29. W tych słowach znajdujemy potwierdzenie powszechnej w środowisku egzulantów goryczy, nostalgii, ale również odczucia degradacji społecznej. Było ono tym bardziej dominujące, że świat, jaki znali, runął wyłącznie dla nich. Rodacy, krewni i znajomi, których majątki pozostały po zachodniej stronie granicy, wracali do dawnego życia.

Stan ducha arystokratów kresowych jeszcze dobitniej kreśli M. Jałowiecki. W swoich wspomnieniach mówi wprost o kompleksie niższości jako „nieprzyjemnej dolegliwości ludzi wyrzuconych z gniazda rodzinnego" ${ }^{30}$. Być może próbą odreagowania tego odczucia było podkreślanie własnej kresowej odrębności czy stanowej wyższości. Wielu pomorskich „rozbitków” odwoływało się do świetnej przeszłości swoich rodów. Julian Ścibor-Marchocki, mimo że nie miał żadnego majątku, a pracował na Pomorzu jako rządca, podkreślał swoje pochodzenie i posiadany tytuł hrabiowski. Dużą satysfakcję sprawiało mu zwracanie się do niego $\mathrm{z}$ użyciem tego tytułu ${ }^{31}$. Być może $\mathrm{z}$ tych samych powodów $\mathrm{E}$. Bielski, wprawdzie przez rewolucję niewydziedziczony, ale niewątpliwie ciężko dotknięty przez wojnę, ogłosił w prasie pod koniec lat dwudziestych odzyskanie przez siebie utraconego tytułu książęcego. Konsekwentnie kazał się tak tytułować, mimo że przedstawiony przez niego wywód genealogiczny został gruntownie skrytykowany w literaturze naukowej. Nawet najbliższa rodzina próbowała mu wyperswadować, aby nie narażał się na śmieszność i wycofał z posługiwania tym niepewnym tytułem. E. Bielski jednak $\mathrm{z}$ uporem trwał w swoim przekonaniu ${ }^{32}$.

Na ziemiach Pomorza wygnańcom kresowym towarzyszyło, jeśli nie poczucie odrzucenia, to przynajmniej pewna forma wyalienowania. W większości nie znali tej ziemi i ludzi, których najczęściej nawet nie rozumieli. Dlatego Julian Ścibor-Marchocki swoje pierwsze chwile w Chojnicach wspomina następująco: „znalazłem się w kraju zupełnie odmiennym od dotychczas znanych”. Trzeba przyznać,

\footnotetext{
${ }^{29}$ Słowo Pomorskie, nr 4 z 6 I 1921 r., s. 3.

${ }^{30}$ M. JAŁOWIECKI, op.cit., s. 533.

${ }^{31}$ Teresa GórsKa, Dzieciństwo moich dzieci. Fragmenty, [in:] Kamienica na pograniczu borowiacko-krajeńskim. Miejsce ludzi - ludzie miejsca, red. Marek SAss, Bydgoszcz-Kamienica 2012, s. 40.

${ }^{32}$ Miesięcznik Heraldyczny, R. 9: 1930, nr 1, s. 9-11; Jan Maleszewski, Książęta Bielscy herbu Pogoń, Warszawa 1929; APB, Kom., sygn. 55, list Edwarda Bielskiego do Tomasza Komierowskiego z 22 IV $1930 \mathrm{r}$.
} 
że miejscowi nie ułatwiali adaptacji przybyszom. Za Julianem Ścibor-Marchockim, którego łatwo było rozpoznać jako „obcego" po wytartym mundurze bez oznaczeń, wykrzykiwano na ulicach „Antek z Kongresówy” lub „Antek wracaj do ciepłych krajów”33. Od początku „kresowcy” starali się otaczać dawnymi krajanami. M. Jałowiecki, organizując swoją placówkę w Gdańsku, na najbliższych współpracowników dobrał sobie Witolda Wańkowicza, rodem z Mińszczyzny, oraz kontradmirała Michała Borowskiego z Wileńszczyzny. Konsekwencją tych decyzji było zatrudnienie na niższych stanowiskach kolejnych osób z kręgu znajomych i rodziny, co było zresztą w późniejszym czasie przyczyną krytyki delegata rządu RP w Gdańsku ze strony lewicowej opozycji. Jednakże premier Ignacy Paderewski odrzucił wówczas honorową dymisję M. Jałowieckiego, wysoce oceniając prace całego zespołu ${ }^{34}$.

Więzy rodzinne decydowały również o relacjach towarzyskich. We dworze Bielskich w Kończewicach do świątecznego stołu zasiadano zwykle wspólnie $\mathrm{z}$ wujem Edwardem Woyniłłowiczem, jego żoną oraz ciotką Michaliną Horwattową, mieszkającymi wówczas w Bydgoszczy. Ci sami goście zaglądali tam również w czasie letnich wakacji czy imienin gospodarzy ${ }^{35}$. Do nowego domu Świackich zjeżdżali dawni krewni i znajomi, zwłaszcza ci, którzy osiedlili się na Pomorzu. W pamiątkowej księdze gości niektórzy z nich obok nazwiska dopisywali krótkie słowa, podkreślające kresowe więzi. Wspomniany W. Wańkowicz podpisał się jako współwygnaniec, a Zdzisława Zaremba-Jarczewska dziękowała za gościnę „kochanym kresowiakom na wygnaniu”. Natomiast Michał Poczobut z Władysławem Hertywiczem dziękowali za powrócenie im wiary w ludzi, którzy potrafią się opierać przeciwnościom losu ${ }^{36}$. Wielu $\mathrm{z}$ nich nie nawiązywało na Pomorzu bliższych znajomości, a w skrajnych przypadkach czuło nie tylko rezerwę, lecz wręcz niechęć do miejscowej ludności. Najdobitniej wyrażała to osiadła w sąsiedniej Wielkopolsce Zofia Grocholska. W odniesieniu do jednego ze znanych i wpływowych ziemian pomorskich pisała wprost: „ta kultura tutejsza nie może się porównać do cywilizacji jaka u nas była na Podolu. Ludzie byli okrzesani, delikatni [...] kiedy tu przeciwnie, wszyscy prawie bez wyjątku są gruboskórzy i gbury - pruska szkoła" ${ }^{\text {"37. }}$ Zatem wzajemny brak zrozumienia, wszechobecne poczucie krzywdy, idealizowanie przeszłości konserwowały niestety podziały regionalne.

Potrzeba integracji tego środowiska zrodziła pomysł utworzenia Stowarzyszenia Polaków Kresów Wschodnich w Toruniu. W jego prace aktywnie włączał się

${ }^{33}$ J. ŚCIBOR-MARCHOCKI, op.cit., s. 92.

${ }^{34}$ M. JAŁOWIECKI, op.cit., s. 446-449, 551-553.

${ }^{35}$ APB, Kom., sygn. 56, listy Franciszki z Komierowskich Bielskiej do Róży z Zamoyskich Komierowskiej z 23 XII 1921 r. oraz 1 V 1923 r.; sygn. 57, list Franciszki z Komierowskich Bielskiej do Róży z Zamoyskich Komierowskiej z 30 IX 1926 r.; sygn. 55, list Franciszki z Komierowskich Bielskiej do Tomasza Komierowskiego z 2 I 1922 r. Por. Gizela Chmielewska, Cierń Kresowy. Opowieść o Edwardzie Woyniłłowiczu i jego rodzinie, Łomianki [2010], s. 216, 221, 249, tam szerzej o losach Edwarda Woyniłłowicza po ucieczce z Kresów i osiedleniu się w Bydgoszczy.

${ }^{36} \mathrm{BN}$, sygn. akc. 11066, „Książka gości”, passim.

${ }^{37}$ Biblioteka Kórnicka PAN, sygn. BK 11799/2, list Zofii z Zamoyskich Grocholskiej do córki Zofii z Grocholskich Krasickiej z 13 VII 1927 r. 
m.in. K. Świacki. Jeszcze jako pełnomocnik Rady Narodowej Ziem Białoruskich zabiegał w stolicy o objęcie granicami Rzeczypospolitej Kresów Wschodnich. Starania Rady nie przyniosły żadnych rezultatów, ponieważ traktat ryski pozostawił w państwie bolszewickim znaczną część polskich Kresów. Podczas zebrania toruńskiego stowarzyszenia K. Świacki z goryczą relacjonował porażkę tych starań, nie szczędząc krytyki rządowi. Traktat ryski w jego opinii niweczył półtorawiekową pracę nad utrzymaniem polskości tych ziem $\mathrm{w}$ okresie zaborczym ${ }^{38}$. Do rozgoryczenia i żalu za rodzinną ziemią doszło poczucie zdrady ze strony własnego rządu.

Jednym z najważniejszych zadań w tym czasie była organizacja pomocy materialnej dla najbardziej potrzebujących współziomków. Najwięcej uwagi i troski poświęcano opiece nad dziećmi, często sierotami lub rozdzielonymi z rodzicami kordonem granicznym. M. Świacka zaangażowała się w prace Pomorskiego Towarzystwa Opieki nad Dziećmi, utworzonego przez ks. Henryka Szumana. Objęła w nim dział sierocińców i kwesty, popularnie nazywany „Ratujcie Dzieci”. Szukając środków materialnych na zabezpieczenie potrzeb dzieci, prowadziła rozległą kwestę za pośrednictwem urzędów, szkół, parafii oraz różnorodnych stowarzyszeń. Organizowane loterie, zabawy karnawałowe, rauty i koncerty przynosiły poważne kwoty, które pomogły setkom dzieci. W początkowej fazie sieroty rozlokowano w ochronkach w Ostrowitem pod Golubiem, Toruniu, Działdowie oraz klasztorach w Chełmnie, Grudziądzu i Lubawie, a starszych chłopców w szkole rzemieślniczej w Chojnicach. M. Świacka pracowała w Towarzystwie do 1924 r., a później jak wiele ziemianek pomorskich pomagała w doraźnych akcjach ${ }^{39}$. Duże zaangażowanie w pomoc dla żeńskiego Internatu Kresowego w Chełmnie włożyła Zofia Ślaska (później Łubieńska), siostrzenica K. Świackiego. Wchodziła ona w skład Rady Opiekuńczej internatu. To w dużej mierze dzięki jej zaangażowaniu Ziemianki Pomorskie otoczyły chełmińską placówkę szczególną opieką. W sytuacji, gdy instytucje państwowe asygnowały zimą 1925/1926 r. na jej cele 1200 zł, ziemianki zebrały w gotówce i produktach (wprawdzie w całym roku szkolnym 1925/1926) przeszło 6000 zł. Ponadto 60 dziewcząt spędzało wakacje w pomorskich dworach, a dalsze 10 mogło pojechać na kurację do Inowrocławia ${ }^{40}$.

Kresowi ziemianie coraz silniej podejmowali próby adaptacji w nowym środowisku. W kwietniu 1923 r. E. Hulewicz, znany na Pomorzu lekarz i ziemianin, witał w Skarszewach prezydenta Rzeczypospolitej Stanisława Wojciechowskiego w imieniu ludności kaszubskiej oraz „kresowców”, którzy na tej ziemi znaleźli

\footnotetext{
${ }^{38}$ Słowo Pomorskie, nr 98 z 30 IV 1921 r., s. 3. Były to zresztą poglądy powszechne w środowisku egzulantów kresowych, por. E. WoyniŁŁowicz, op.cit., s. 296-297; Hipolit Korwin-Milewski, Siedemdziesiąt lat wspomnień (1855-1925), Poznań 1930, s. 560-565.

${ }^{39}$ Maria Świacka, „Wspomnienia Marii z Donimirskich Świackiej”, rękopis spisany w latach dwudziestych / trzydziestych XX w., w zasobie: BN, sygn. akc. 10629, k. 10-11.

${ }^{40}$ Ziemianka Pomorska, nr 13 z 2 VIII 1925 r., s. 2; nr 17 z 4 X 1925 r., s. 1; Słowo Pomorskie, nr 34 z 12 II 1926 r., s. 4. Analogiczny internat dla chłopców z Kresów Wschodnich działał w pobliskiej Bydgoszczy, por. Gizela CHMIELEwsKa, Internat Kresowy w Bydgoszczy 1920-1936, Kronika Bydgoska, t. 34: 2013, s. 129-162.
} 
nową ojczyznę. Zwrócenie uwagi w mowie powitalnej na imigrantów świadczy o postępującym procesie integracyjnym. Trzeba jednak podkreślić, że dr E. Hulewicz pozwolił sobie na pewien wątek osobisty, sam bowiem od niedawna był teściem kresowego wygnańca, wspominanego Juliana Ścibor-Marchockiego ${ }^{41}$. Ten ostatni szybko dał się poznać jako aktywny działacz wielu organizacji społecznych, m.in. prezes koła Towarzystwa „Sokół” w Rumii ${ }^{42}$. Z kolei K. Świacki, gospodarując w swojej niewielkiej Przystani, będąc jednocześnie wiceprezesem Kółka Rolniczego w Chełmży, organizował wycieczki rolnicze po przodujących gospodarstwach $\mathrm{w}$ okolicy ${ }^{43}$. Ten system edukacji rolniczej z powodzeniem prowadził jeszcze w czasie swojej obecności na Białorusi. W 1908 r. zainicjował wycieczkę ziemian guberni mohylewskiej po gospodarstwach rolnych i majątkach ziemskich na terenie Danii i Szwecjii ${ }^{44}$. Idąc tym śladem, współtworzył w powiecie toruńskim w 1927 r. Koło Porad Sąsiedzkich. Jego członkowie zakładali, że naukę o gospodarowaniu najlepiej zdobywać przez dzielenie się własnym doświadczeniem. Dlatego objeżdżali wspólnie własne gospodarstwa i podejmowali dyskusje o zaletach i wadach przyjętych rozwiązań. Organizowali również wycieczki na sąsiadujące ziemie Kujaw i Wielkopolski, aby przyglądać się tamtejszym sposobom uprawy. Gromadzili bogatą dokumentację fotograficzną, a swoje spostrzeżenia publikowali w prasie rolniczej ${ }^{45}$. K. Świacki nie stronił też od aktywności politycznej, był bowiem członkiem zarządu koła Chrześcijańsko-Narodowego Stronnictwa Rolniczego w Chełmży ${ }^{46}$. Z kolei S. Kozakowski wchodził w skład rad nadzorczych Pomorskiego Stowarzyszenia Rolniczo-Handlowego oraz Pomorskiego Syndykatu Rolniczego, znajdując się w grupie najbardziej wpływowych ziemian pomorskich. Był jednocześnie prezesem oddziału tczewskiego wspomnianego stowarzyszenia handlowego ${ }^{47}$. Należał do współzałożycieli oddziału Pomorskiej Ligii Obrony Powietrznej Państwa w Tczewie ${ }^{48}$. Z grona pracodawców został wybrany jako zastępca ławnika trybunału do spraw ubezpieczeń społecznych w Poznaniu ${ }^{49}$. Podobnie jak K. Świacki angażował się również w działalność polityczną, wspierając w połowie lat dwudziestych pomorską endecję $e^{50}$. W opinii policyjnej wiązał się z ruchem monarchistycznym, choć nie figurował w oficjalnym wykazie członków tego ugrupowania $a^{51}$.

\footnotetext{
${ }^{41}$ Kłosy, nr 19 z 13 V 1923 r., s. 301.

${ }^{42}$ APG, O/Gdynia, SMW, sygn. 99, s. 270.

${ }^{43}$ Słowo Pomorskie, nr 152 z 7 VII 1926 r., s. 5.

${ }^{44} \mathrm{BN}$, sygn. AFF.II - 43, passim.

${ }^{45}$ Karol Świacki, Wycieczka do Łabiszynka, Kłosy, nr 34 z 21 VIII 1927 r., s. 785-786; idem, Wycieczka Toruńskiego Koła Porad Sąsiedzkich na Kujawy, ibid., nr 33 z 12 VIII 1928 r., s. 803-807.

${ }^{46}$ Przyjaciel Rolnika, nr 27 z 5 III 1925 r., s. 3.

${ }^{47}$ APB, Komenda Okręgowa Policji Państwowej w Toruniu (dalej cyt. KOPPT), sygn. 75, brak paginacji; Pomorski kalendarz rolniczy na rok 1926, Toruń 1925, s. 247.

${ }^{48}$ Księga pamiątkowa Pomorskiej Ligii Obrony Powietrznej Państwa, Toruń 1925, s. 66.

${ }^{49}$ Słowo Pomorskie, nr 286 z 12 XII 1926 r., s. 13.

${ }^{50}$ Ibid., nr 22 z 28 I 1926 r., s. 7.

${ }^{51} \mathrm{APB}, \mathrm{KOPPT}$, sygn. 75, brak paginacji.
} 
$\mathrm{Na}$ koniec należy postawić pytanie, czy udało się ziemianom kresowym na trwałe osiąść i zasymilować ze społecznością pomorską. Odpowiedź na nie jest złożona. Część imigrantów, jak Karol Świacki, Aleksander Bolcewicz, Medard Komar czy mieszkający w pobliskiej Bydgoszczy Edward Woyniłłowicz, zmarła przed drugą wojną światową i spoczęli na zawsze w ziemi pomorskiej czy kujawskiej. Jednak już ich dzieciom nie udało się dłużej pozostać na Pomorzu. Stanisław Świacki, który przejął po ojcu Przystań, pracował jednocześnie jako urzędnik bankowy. Pomimo nostalgii za ziemiańskim życiem, którego namiastką było gospodarstwo pod Chełmżą, nie wytrzymał warunków kryzysu gospodarczego. W 1934 r. sprzedał Przystań i przeniósł się z rodziną do Kielc, gdzie piastował posadę w Banku Rolnym ${ }^{52}$. Podobnie uczyniła wdowa Zofia Bolcewicz: sprzedała swoje gospodarstwo i przeniosła się z córką do Wilna ${ }^{53}$. Z kolei Julian Ścibor-Marchocki opuścił Pomorze na początku lat trzydziestych, kiedy otrzymał posadę administratora w dobrach Żółtowskich na Wileńszczyźnie ${ }^{54}$. Swój majątek pod Tczewem sprzedał nawet S. Kozakowski, odnoszący przecież znaczne sukcesy hodowlane. Ciężko chory przeniósł się do Zakopanego, gdzie wkrótce zmarł i tam został pochowany ${ }^{55}$. Jak wspomniano, na Pomorzu nie udało się pozostać M. Jałowieckiemu, który osiadł w majątku żony w ziemi kaliskiej. Na skutek parcelacji E. Bielski musiał zrezygnować z dzierżawy Kończewic w 1930 r., przenosząc się do rodowej Atteczyzny. Kłopoty finansowe pchnęły go do fałszowania weksli swojego szwagra, a jednocześnie ministra rolnictwa - Leona Janty-Połczyńskiego. Afera przyniosła niebywały skandal, a pomorska rodzina Bielskiego odsunęła się odeń niemal całkowicie ${ }^{56}$.

Swoje niewielkie folwarki na przedmieściach Kościerzyny sprzedali zarówno Ledóchowscy, jak i Grocholscy. Ci pierwsi mieli paść ofiarą własnej niezaradności, natomiast drudzy nietrafionych interesów oraz nadmiernej skłonności pana domu do alkoholu. Zresztą w opinii Juliana Ścibor-Marchockiego uciekinierzy ze wschodu nie mogli się zaadoptować na Pomorzu, gdyż nie umieli zrezygnować $\mathrm{z}$ wysokiej stopy życiowej. Nie potrafili również na niewielkich folwarkach podjąć samodzielnej pracy, jak często czynili to Pomorzanie ${ }^{57}$. Z prezentowanych pomorskich „życiowych rozbitków” pozostali tutaj tylko Meysztowiczowie i Puzynowie, którzy posiadali duże i dobrze zagospodarowane majątki ziemskie. W obu przypadkach małżonki kresowych ziemian pochodziły z zachodniej części Polski.

\footnotetext{
${ }^{52}$ Maria ŚWIACKA, „Wspomnienia”, maszynopis sporządzony w oparciu o notatki odręczne przez synową Barbarę z Korzeniowskich Świacką około 1970 r., w zasobie: BN, sygn. akc. 11063, k. 37.

${ }^{53}$ G. PierzynowsKa, op.cit., s. 375.

${ }^{54}$ S. ŚCIBOR-MARCHOCKI, op.cit., s. 8-9.

${ }^{55}$ Nagrobek Stanisława Kozakowskiego znajduje się na cmentarzu w Zakopanem („Na Palenicy"), przy ul. Nowotarskiej 41.

${ }^{56}$ Słowo Pomorskie, nr 125 z 30 V 1935 r., s. 8; nr 130 z 6 VI 1935 r., s. 2; nr 136 z 14 VI 1935 r., s. 9; Gazeta Bydgoska, nr 45 z 24 II 1933 r., s. 1; nr 87 z 14 IV 1933 r., s. 7; Kurier Bydgoski, nr 241 z 20 X 1934 r., s. 3; nr 285 z 8 XII 1935 r., s. 5; APB, Kom., sygn. 48, list Edwarda Bielskiego do Marii z Kurnatowskich Komierowskiej z 27 I 1935 r.

${ }^{57}$ J. ŚcIBOR-MARCHOCKI, op.cit., s. 95, 98.
} 
Piecewo było wszak rodowym majątkiem Marii z Gółkowskich Meysztowiczowej, natomiast Gronowo zostało zakupione najprawdopodobniej z posagu Marii Letycji z Zielińskich Puzynowej.

Należy jednak zwrócić uwagę, że utrata majątków ziemskich na Pomorzu w okresie kryzysu nie była zjawiskiem odosobnionym. Przedstawiciele wielu starych pomorskich rodów nie potrafili przystosować swoich gospodarstw do nowych warunków ekonomicznych ${ }^{58}$. Przedłużający się okres dekoniunktury, obciążenia podatkowe i socjalne napędzały spiralę kredytową. Majątki będące niegdyś źródłem bogactwa popadały w długi, przekraczające nawet dwukrotnie wartość gospodarstw. W takich warunkach ziemianie byli zmuszeni parcelować lub nawet sprzedawać całe folwarki. Nie były to już sytuacje wyjątkowe, bankructwa majątków stały się powszechne. Stanisław Kurnatowski z Wielkopolski donosił siostrze, że „tu w okolicy wszystko zbankrutowało. Es ist traurig, aber wahr!”. Jednocześnie dodawał słowa, które można uznać za prawdziwy paradygmat ziemiański: „Może Bóg da, że człowiek się jakoś utrzyma na tej ukochanej Ojcowiźnie"59. Ziemian kresowych, którzy próbowali się osiedlać na Pomorzu i prowadzić tutaj gospodarstwa rolne, dotknęły te same procesy, tylko nieco wcześniej. Nie mieli dostatecznego zabezpieczenia finansowego ani kredytowego, dlatego szybciej decydowali się na sprzedaż majątku. Zwłaszcza młodsi przejawiali daleko większą mobilność i odważniej podejmowali decyzje o zmianie miejsca zamieszkania. Mieli w sercu tylko jedną, kresową, ojczyznę, dlatego nie czuli specjalnego sentymentu do ziemi pomorskiej. Raz wyrzuceni ze swoich dóbr łatwiej adaptowali się do nowych warunków.

dr hab. Tomasz Łaszkiewicz

Instytut Historii PAN

e-mail: tomasz.laszkiewicz@interia.pl

${ }^{58}$ Por. T. Łaszkiewicz, Ziemiaństwo na Pomorzu, s. 63-80; idem, Przeobrażenia społeczno-gospodarcze ziemiaństwa pomorskiego po pierwszej wojnie światowej na przykładzie rodziny Sikorskich $z$ Wielkich Chetmów, Zapiski Historyczne, t. 73: 2008, z. 4, s. 47-66.

${ }^{59}$ APB, Kom., sygn. 52, list Stanisława Kurnatowskiego do Marii z Kurnatowskich Komierowskiej z 22 V 1931 r. 
GUTSBESITZER AUS DEN OSTGEBIETEN ALS EXILANTEN IN POMMERN NACH DEM 1. WELTKRIEG

\section{Zusammenfassung}

Schlüsselwörter: Gutsbesitzer, Flüchtlinge, Migrationen, polnische Ostgebiete, Wojewodschaft Pommern, Zweite Republik

Die bolschewistische Offensive nach Polen in den Jahren 1919/20 zwang Gutsbesitzer, die seit Generationen in den Ostgebieten der alten Adelsrepublik lebten, zur überstürzten Flucht von ihren Gütern. Die Festlegung der polnischen Ostgrenze beim Vertrag von Riga führte dazu, dass eine Rückkehr in die Heimat für einen bedeutenden Teil dieser Gruppe nicht möglich war. Die geflüchteten Gutsbesitzer aus den Ostgebieten hatten nicht nur ihre Häuser und ihr Land verloren, sondern auch ihre finanziellen Mittel. Sie tauchten zahlreich in den großen städtischen Zentren auf, wo sie versuchten Arbeit und Existenzmittel zu finden. Andere kauften von den Resten ihres früheren Kapitals kleine Landwirtschaften in den Grenzen der wiedererstandenen Republik. Pommern war in dieser Hinsicht attraktiv, denn es war von zahlreichen Deutschen verlassen worden, die hier zuvor gelebt hatten. Die Einwanderer aus den Ostgebieten bemühten sich unter Schwierigkeiten, sich an die neuen Lebens- und Arbeitsbedingungen zu gewöhnen. Sie waren gesellschaftlich degradiert und lebten in Erinnerungen an die Vergangenheit und im Schmerz um das verlorene Vaterland. Sie fühlten sich von der polnischen Regierung ungerecht behandelt, unverstanden und entfremdet. Oft war es für sie schwierig, bisherige Gewohnheiten bei der Bewirtschaftung des Landes aufzugeben, und so scheiterten sie unter den andersartigen wirtschaftlichen Bedingungen und auf den viel kleineren landwirtschaftlichen Flächen. Die Jüngeren unter ihnen erwiesen sich als mobiler und fanden leichter Arbeit. Zugleich fühlten sie keine große Verbundenheit mit Pommern und trafen leicht die Entscheidung, diese Region zu verlassen.

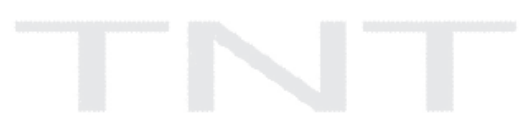




\section{LANDOWNERS EXILED FROM THE EASTERN BORDERLANDS IN POMERANIA} AFTER WW I

\section{Summary}

Key words: landowners, refugees, migrations, the Eastern Borderlands, the Pomeranian voivodeship, the Second Polish Republic

The Bolshevik offensive against Poland during the years 1919-1920 forced landowners who had lived in the Eastern Borderlands for generations to escape hastily from their estates. The formation of the Polish border in the east after the treaty of Riga made it impossible for most of them to return to their family lands. The refugees from the Eastern Borderlands were not only deprived of their houses and land, but also financial resources. They arrived in large numbers in the major cities where they tried to find work and some financial means of survival. Other landowners purchased small farms in the new Rzeczpospolita. The most attractive were farms in Pomerania abandoned by the Germans. Immigrants from the Eastern Borderlands found it hard to adapt to new conditions of life and work. Demoted socially, they indulged in nostalgia for the past and longing for their lost motherland. They felt insulted by the Polish government, misunderstood and alienated. It was frequently difficult for them to renounce their old habits in administering their estates, which meant that they often failed to succeed in the changed economic circumstances and on a much smaller area of land. Younger landowners exhibited a greater mobility and found it easier to find work. They did not feel attached to the Pomeranian land and found it easier to make the decision to leave the region.

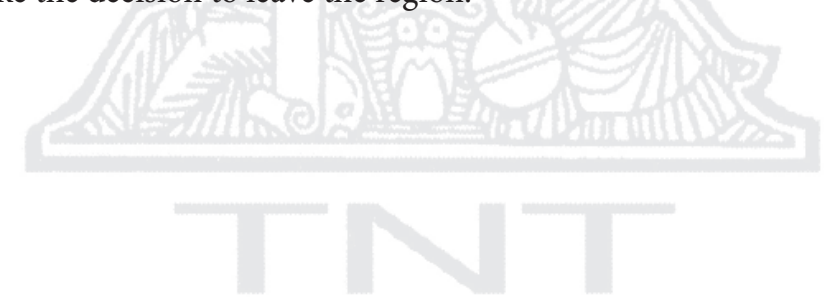

